\title{
Potential Screening of Bacteriocinogenic-Lactic Acid Bacteria from Mangrove Sediment of Logending Beach for Fisheries Product Preservation
}

\author{
Dyah Fitri Kusharyati ${ }^{1 *}$, Taruna Dwi Satwika ${ }^{1}$, Afifah Mariana ${ }^{1}$, Anwar Rovik ${ }^{2}$ \\ 1)Laboratory of Microbiology, Department of Microbiology, Faculty of Biology, Universitas Jenderal Soedirman. Jl. DR. Soeparno \\ No. 63, Grendeng, Purwokerto Utara, Banyumas, Jawa Tengah, Indonesia 53122 \\ 2) Centre of Tropical Medicine. Faculty of Medicine, Public Health, and Nursing, Universitas Gadjah Mada. Jl. Teknika Utara, \\ Kocoran, Depok, Sleman, Yogyakarta, Indonesia 55281 \\ * Corresponding author, email: dfitri.k@gmail.com
}

Submitted: 06 December 2020; Accepted: 08 March 2021; Published online: 01 April 2021

\begin{abstract}
The meat and fisheries products have high nutritional content which is highly ideal for bacterial growth. Lactic Acid Bacteria (LAB) have several potential advantages as a bio-preservative agent in the food industry because they produce antimicrobial substances against pathogenic bacteria e.g. bacteriocin. Our previous study has succeeded in isolating and characterizing LAB from the mangrove sediments of Logending Beach, Kebumen. This present study aimed to determine the activity of bacteriocinogenic-LAB against food-borne pathogens and their potential for fisheries product preservation. The study consisted of five serial stages, as follows: screening of $\mathrm{LAB}$ isolates, cell-free supernatant production and its inhibition activity, extraction of partially purified bacteriocin, bacteriocin confirmation against proteolytic enzymes, and in-vitro test of partially-purified bacteriocin against Listeria monocytogenes, Shigella flexneri, and Salmonella typhi. A total of 25 out of 99 isolates were able to grow on $\mathrm{MRSA}+1 \% \mathrm{CaCO}_{3}$ medium. Initial screening showed that the cell-free supernatant of $14 \mathrm{LAB}$ isolates was able to inhibit the growth of S. thypi, S. flexneri, and L. monocytogenes. There was an increased inhibitory activity of partially purified bacteriocin when compared with the cell-free supernatant which was statistically different $(\mathrm{p}<0.01)$. It indicated that the purification was successfully performed. Bacteriocin expressed a lower inhibition against $S$. typhi than L. monocytogenes and S. flexneri. The ANOVA test showed that each indicator pathogenic-bacterium expresses a very significant sensitivity to the partially purified bacteriocin.
\end{abstract}

Keywords: Bacteriocin, fisheries product, LAB, mangrove sediments, food-borne pathogens

\section{INTRODUCTION}

The human population in the world is increasing rapidly which influences the high demand for food availability. In this modern era, the safety, quality, and health profile of food products are being a big concern. The meat and fisheries products have high nutritional content. On the other hand, they are highly ideal for bacterial growth e.g. Listeria monocytogenes, Salmonella spp., and Shigella spp. which cause food-borne diseases (Jennison \& Verma 2004;

Novotny et al. 2010). 
Bacterial contamination of seafood and its products affects the nutritional properties or undesirable organoleptic changes. The contamination may take place during harvesting, handling, preparation, processing, transportation, and storage. Many food treatments have been applied to control bacterial contamination, such as salt administration, smoking, canning, freezing, and vacuum application. However, these treatments are not sufficient to kill pathogenic microorganisms since some bacteria have been reported to be resistant to high salt concentration, drying, freezing, and heat processes (Dupard et al. 2006).

Bio-preservation is a promising approach to control bacterial contamination and extend the shelf life of foods, including the application of living microorganisms and their metabolites (Moradi et al. 2020). Bacteriocin, a secondary metabolite of Lactic Acid Bacteria (LAB), has several potential advantages as a bio-preservative agent in the food industry including (a) generally recognized as safe substances, (ii) inactive and nontoxic on eukaryotic cells, (iii) inactivated by digestive proteases, (iv) usually $\mathrm{pH}$ and heat-tolerant, and (v) have a relatively broad antimicrobial spectrum against many food-borne pathogenic and spoilage bacteria (Siedler et al. 2019).

$\mathrm{LAB}$ are reported to be able to produce antimicrobial substances, such as carbon dioxide, diacetyl, acetaldehyde, ethanol, hydrogen peroxide, and bacteriocin (de-Vuyst \& Leroy 2007; Liao \& Nyachoti 2017). Bacteriocin has bactericidal or bacteriostatic effects (Cheong et al. 2014; Gerez et al. 2013; Yang et al. 2012) against various foodborne pathogens, such as Staphylococcus aureus, Bacillus cereus, L. monocytogenes, Clostridium botulinum, and E. coli (Aunpad et al. 2007; Dobson et al. 2012).

LAB are commonly isolated from fermented food products, milk, and the intestinal tract of humans or animals (Dobson et al. 2012; Kusharyati et al. 2020). Meanwhile, only a few studies isolated LAB from soils, water, and plants. Mangroves are unique ecosystems that harbor unique and diverse microorganism groups, such as fungi, actinomycetes, and bacteria. Our previous study has succeeded in isolating and characterizing LAB from the mangrove sediments of Logending Beach, Kebumen. This present study aimed to determine the activity of bacteriocinogenic-LAB against food-borne pathogens and their potential for fisheries product preservation.

\section{MATERIALS AND METHODS}

The study consisted of five serial stages, as follows: screening of LAB isolates, cell-free supernatant production and its inhibition activity, production of partially-purified bacteriocin, bacteriocin confirmation against proteolytic enzymes, and in-vitro test of partially purified bacteriocin against L. monocytogenes, Shigella flexneri, and Salmonella typhi.

\section{Screening of bacteriocinogenic-LAB}

One loop of isolates originating from mangrove sediments of Logending Beach Kebumen was grown on the de-Man Rogose Sharpe Agar (MRSA) medium (Oxoid) which was supplemented with $1 \% \mathrm{CaCO}_{3}$. The spot inoculation was performed triplicate in each dish. Bacterial incubation was carried out for 48 hours at $37^{\circ} \mathrm{C}$. Isolates that expressed a clear zone around the growing colony were assumed as Lactic Acid Bacteria. The bacterial characterization was performed following Hendrati et al. (2017). The selected isolates were stocked on MRSA slant medium. The pathogenic bacteria, $S$. typhi, and S. flexneri were re-cultured using Salmonella Shigella Agar (SSA) medium (Merck), meanwhile, L. monocytogenes using Nutrient Agar (NA) medium (Merck). 
Pre-screening of $L A B$ 's inhibition activity

One loop of LAB isolate was inoculated in MRS Broth (MRSB) medium and incubated for 18 hours at $37^{\circ} \mathrm{C}$. The bacterial culture was centrifuged for 10 minutes at 10,000 rpm to obtain a bacterial cell-free supernatant (CFS). Its inhibition activity was evaluated using Kirby's Bauer method by following Hendrati et al. (2017). The pathogenic bacteria were inoculated on Nutrient Broth $(\mathrm{NB})$ medium $(1 \% \mathrm{v} / \mathrm{v})$, then was incubated for 8 hours at $37^{\circ} \mathrm{C}$. The pathogenic bacteria were spread on NA medium. A $6 \mathrm{~mm}$ diameter paper disc was dropped by $20 \mu \mathrm{L}$ of cell-free supernatant, then was placed into the pathogenic bacterial lawn-medium. The assay was performed triplicate in each dish. Incubation was carried out for 24 hours at $37^{\circ} \mathrm{C}$. The formed inhibition zone was observed and calculated.

Production of partially-purified bacteriocin

One loop of LAB isolates was inoculated into $10 \mathrm{~mL}$ MRSB medium, then was incubated for 18 hours at $37^{\circ} \mathrm{C}$. This culture was used as an inoculum. One milliliter $\left(\sim 10^{8} \mathrm{CFU} / \mathrm{mL}\right)$ of inoculum was inoculated into $100 \mathrm{~mL}$ MRSB medium, then was incubated at $37^{\circ} \mathrm{C}$ for 24 hours. The 24 -hour LAB culture was cold-centrifuged (Thermo Scientific) at 10,000 rpm, $4^{\circ} \mathrm{C}$ for 10 minutes. The supernatant was salted out by adding ammonium sulfate. The mixture was homogenized using a magnetic stirrer. The 50\% ammonium sulfate was slowly added to gradually precipitate the bacteriocin until the end of saturation. The precipitated bacteriocin was separated from the mixture by performing a cold-centrifugation at 10,000 rpm for 15 minutes. Then, the partially-purified bacteriocin was dissolved into $2 \mathrm{~mL}$ of $0.1 \mathrm{M}$ phosphate buffer saline (PBS) with $\mathrm{pH}$ 5.3.

Bacteriocin confirmation against proteolytic enzymes A total of $200 \mu \mathrm{L}$ partially-purified bacteriocin was mixed with $20 \mu \mathrm{L}$ of proteolytic enzyme solution (one gram of proteolytic 'papain' enzymes was dissolved into $1 \mathrm{~mL}$ of $0.1 \mathrm{M}$ PBS with $\mathrm{pH} 5.3$ ), then was incubated at $37^{\circ} \mathrm{C}$ for 2 hours. Its inhibition activity was evaluated using Kirby's Bauer method by following Hendrati et al. (2017). The degraded bacteriocin did not show a clear zone around the paper disc (Nithya et al. 2012).

In-vitro test of partially-purified bacteriocin against pathogenic bacteria

The inhibition activity of crude bacteriocin was evaluated using Kirby's Bauer method following by following Hendrati et al. (2017). The diameter of the inhibition zone expressed by CFS and partially-purified bacteriocin were then compared to evaluate the success of bacteriocin extraction.

Data analysis

The data of inhibitory activity of partially-purified bacteriocin against pathogenic bacteria was analyzed by using an analysis of variance (ANOVA) at $95 \%$ and $99 \%$ levels of confidence.

\section{RESULTS AND DISCUSSION}

The consumption of seafood in various countries is increasing since the global population is increasing rapidly (Elbashir et al. 2018). Food spoilage results in undesirable odor, texture, and appearance which make it unfit for consumption (Odeyemi et al. 2020). LAB is effective to enhance the shelf life of food products and inhabit undesirable microorganism growth in food ( $\underline{\mathrm{X}}$ et al. 2018). Therefore, LAB has been broadly applied in various food industries. Food industries commonly use individual and/or consortium of different LAB, including genera Lactococcus sp., Streptococcus sp., Pediococcus sp., 
Enterococcus sp., Lactobacillus sp., Leuconostoc sp., and Weissela sp. (Hamad et al. 2020; Mokhtar et al. 2016; Nithya et al. 2012).

In this present study, we screened and determined the inhibitory activity of bacteriocinogenic-LAB against food-borne pathogens. A total of 99 bacterial isolates originating from mangrove sediment of Logending Beach (unpublished data) were grown on $\mathrm{MRSA}+1 \% \mathrm{CaCO}_{3}$ as a selective medium for Lactic Acid Bacteria groups. A total of 25 isolates were able to grow on MRSA $+1 \% \mathrm{CaCO}_{3}$ medium and expressed a clear zone around the colonies. It indicated the ability of bacteria to grow and dissolve the $\mathrm{CaCO}_{3}$ in the medium (Mahulette et al. 2016). Gram-positive, non-spore-forming, and Catalase negative isolates were selected for further analysis (data not shown). Pringsulaka et al. (2012) described a LAB as Gram-positive, nonspore-forming, cocci, cocci-bacilli, or rods-shape cells, have anaerobic respiration, and Catalase-negative.

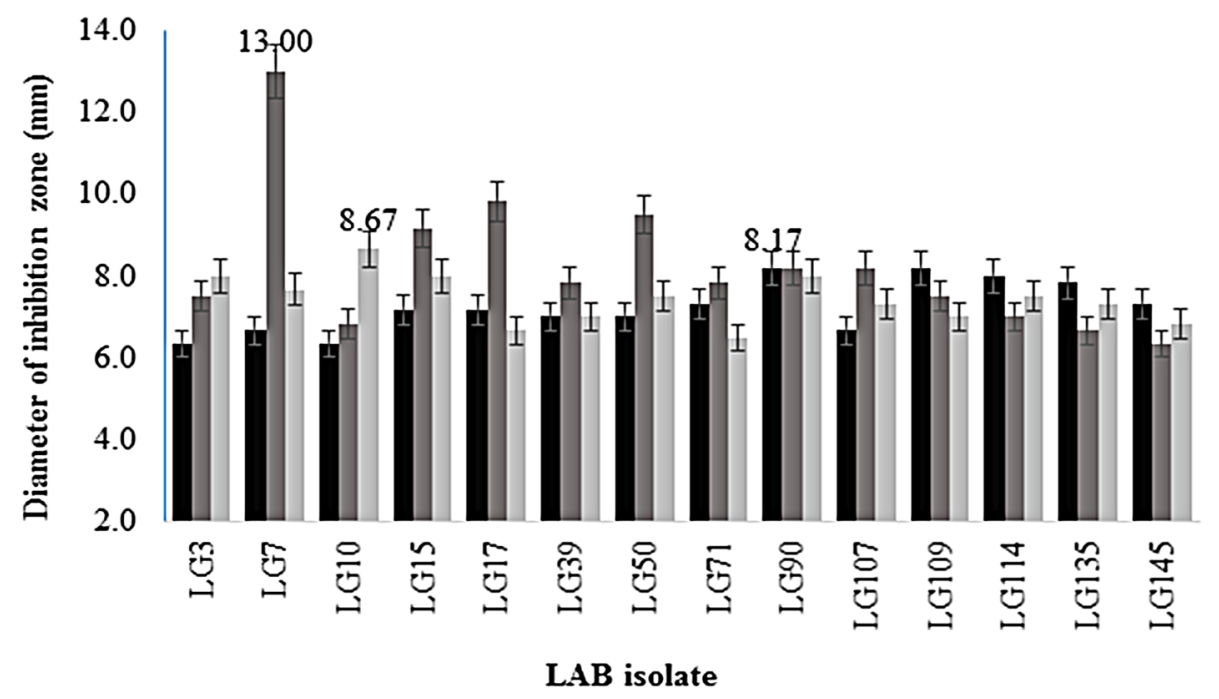

$\square$ S. typhi $\square$ S. flexneri $\square$ L. monocytogenes

Figure 1. The diameter of the inhibition zone of cell-free supernatant against pathogenic bacteria.

Garrido et al. (2012) reported three major foodborne pathogens affecting people worldwide are Salmonella spp., Shigella spp., and Listeria monocytogenes. Salmonella genus is the leading cause of food-borne outbreaks and remains a major public health concern. Salmonella spp. are Gramnegative, rod-shaped, facultatively anaerobic, usually motile, Catalasepositive, and Oxidase-negative. Salmonella produces enterotoxins and causes inflammatory reactions and diarrhea. Symptoms often start 12-72 hours after the ingestion of contaminated food. Salmonella infections from the consumption of seafood products are most commonly associated with raw, undercooked, and poorly cooked seafood (Iwamoto et al. 2010).

Shigella spp. are reported as the third most frequently isolated bacteria from foodstuffs ( $\mathrm{WHO} 2005)$. Shigella flexneri is reported as responsible for shigellosis outbreaks in developing countries (Shahin et al. 2018). Shigella spp. are Gram-negative, rod-shaped, non-motile, Oxidase-negative, and nonlactose fermenting bacteria. Shigella produces enterotoxin 1 and 2 which causes watery loose stool, fever, abdominal pain, and bloody diarrhea ( $\underline{\text { Scallan }}$ et al. 2011).

Listeria monocytogenes is a Gram-positive, rod-shaped, non-sporeforming, Catalase-positive, and glucose fermenter. The bacterium can adapt to various environmental conditions such as a broad range of temperatures, $\mathrm{pH}$, and high salt content (Aspri et al. 2017). Food including seafood 
contamination by L. monocytogenes is recognized as a public health and food safety concern since early 1981 . The transmission to humans is mainly through the consumption of ready-to-eat foods (Miya et al. 2010).

The LAB cell-free supernatant was tested against both Gram-negative and positive pathogenic bacteria i.e. S. typhi, S. flexneri, and L. monocytogenes. A total of $14 \mathrm{LAB}$ isolates could inhibit all tested pathogenic bacteria. This is indicated by the presence of a clear zone or zone of inhibition around the paper disc (previously dropped by cell-free supernatant) on the bacterial lawn. The largest inhibition against $S$. typhi was shown by LAB isolate LG109 with an average diameter of $8.17 \mathrm{~mm}$. The largest inhibition against $S$. flexneri was shown by LAB isolate LG7 with an average diameter of $13.00 \mathrm{~mm}$. While the largest inhibition against $L$. monocytogenes was shown by LAB isolate LG10 with an average diameter of $8.67 \mathrm{~mm}$. All LAB isolates express a broad and strong inhibition (Figure 1). Pan et al. (2009) categorized the more than 6 $\mathrm{mm}$ clear zone expresses a strong inhibition activity, a 3-6 $\mathrm{mm}$ clear zone as moderate, while a 0-3 mm clear zone as weak inhibitory. Some research reported the antimicrobial activity of bacteriocin against both Gram-negative and positive bacteria (Cotter et al. 2005; Duranti et al. 2017; Martinez et al. $\underline{2013})$.

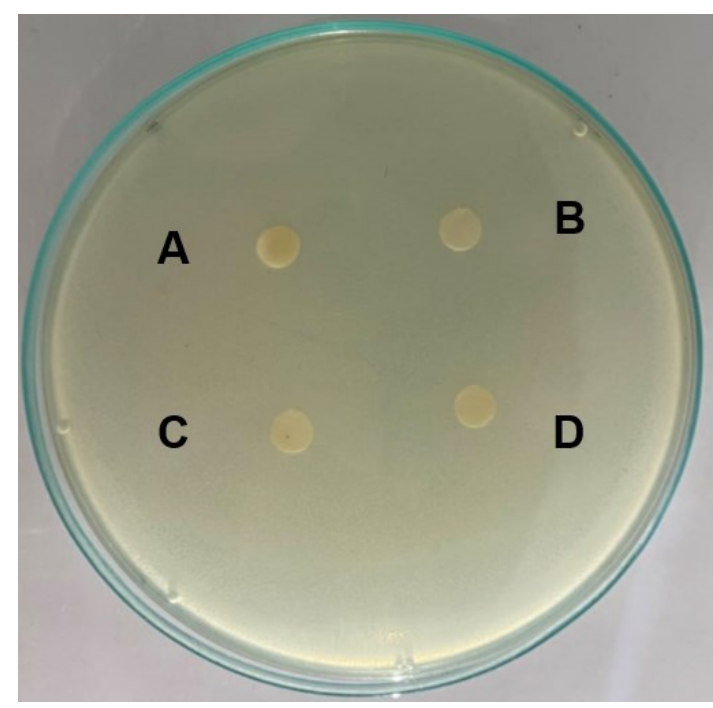

Figure 2. Bacteriocin confirmation against proteolytic enzymes, no clear zone was shown around the paper disc (A: isolate LG50, B: isolate LG135, C: isolate LG73, D: isolate LG17).

The presence of bacteriocin was confirmed by mixing the cell-free supernatant with proteolytic enzymes. Confirmatory tests of CFS extracted from all LAB isolates showed no clear zone presence around the paper disc which indicated the loss of their inhibition activity against pathogenic bacteria (Figure 2). Bacteriocin is proteinaceous in nature which could be inactivated by a proteolytic enzyme (Nithya et al. 2012; Yang et al. 2012). Therefore, it was agreed that bacteriocin is present in the cell-free supernatant.

Cell-free supernatant may contain bacteriocins, organic acids, enzymes, alcohols, and low-molecular-mass substances which are the main metabolites responsible for the antimicrobial action of LAB (Chen et al. 2003). The salted -out method was performed to partially purify the bacteriocin and removing other substances. To evaluate the success of bacteriocin partial purification, we monitor their inhibition activity against pathogenic bacteria. The partiallypurified bacteriocin showed a bigger clear zone than the cell-free supernatant (Figure 3). However, the total inhibition zone diameter was varied among isolates. The largest inhibition zone was shown by LAB isolate LG7 against 


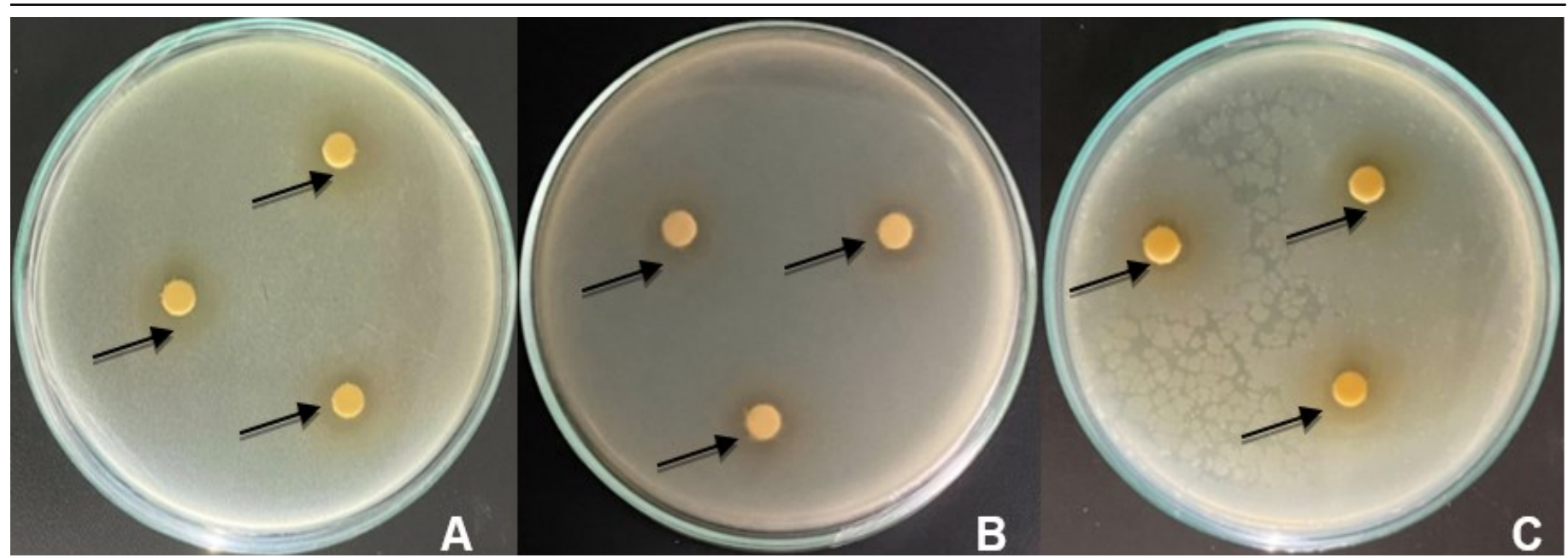

Figure 3. The inhibition zone of partially-purified bacteriocin against S. typhi (A), S. flexneri (B), L. monocytogenes (C), (black arrow pointed the formed clear zone).

S. flexneri with an average diameter of $14.67 \mathrm{~mm}$, followed by LAB isolate LG71 against $L$. monocytogenes with $15.17 \mathrm{~mm}$ in diameter.

Bacteriocin can inhibit the growth of pathogenic bacteria due to the electrostatic interactions between positively charged bacteriocin and negatively charged cytoplasmic membrane lipids. The hydrophobic part of the bacteriocin will enter the cytoplasmic membrane by forming pores. This pore formation will cause the failure of the proton motive force (PMF). PMF is a proton that forms energy to be used in various cell activities including bacterial cell metabolism (Chen et al. 2003; Perez et al. 2014). On the other hand, the bacteriocin-producing bacteria has its immunity to the produced bacteriocin with a specific immune system (Martinez et al. 2013).

There was an increased inhibitory activity of all the partially purified bacteriocin when compared with the cell-free supernatant (Figure 4). It indicated that the purification was successfully performed. Also, these results were statistically significant $(\mathrm{p}<0.01)$. The lower activity of cell-free supernatant might be due to the presence of various metabolites. Moradi et al. (2020) suggested that the biological activity of bacteriocin is attributed to the purification process. Moreover, different purification methods of bacteriocin might result in different levels of purification and yields.

The inhibitory action of bacteriocin can vary between identical species within- and inter-genera (Castellano et al. 2004). The data showed that bacteriocin expressed a lower inhibition against $S$. typhi than L. monocytogenes and $S$. flexneri. The ANOVA test showed that each pathogenic bacterium expresses a very significant sensitivity to the partially-purified bacteriocin (Table 1). The high sensitivity was shown by $S$. flexneri, L. monocytogenes, and $S$. typhi, respectively. Interestingly, the inhibitory activity of bacteriocin against S. flexneri (Gram-negative) was higher than L. monocytogenes (Gram-positive bacteria). Gram-negative bacteria are generally resistant to the bacteriocin produced by Gram-positive bacteria due to their outer membrane acts as an effective and protective barrier (Cao-Hoang et al. 2010). However, Caridi (2002) studied Lactobacillus paracasei and its strong activity of bacteriocin against Escherichia coli.

Table 1. DMRT test of bacterial sensitivity to partially-purified bacteriocin.

\begin{tabular}{lc}
\hline Pathogens & Average of total inhibition zone (mm) \\
\hline S. typhi & $8.83 \pm 1.09^{\mathrm{a}}$ \\
L. monocytogenes & $9.30 \pm 1.57 \mathrm{~b}$ \\
S. flexneri & $10.38 \pm 1.58^{\mathrm{c}}$ \\
\hline
\end{tabular}


12.00

a)

- CFS = Partially Purified

琶

10.00

I I I I I I

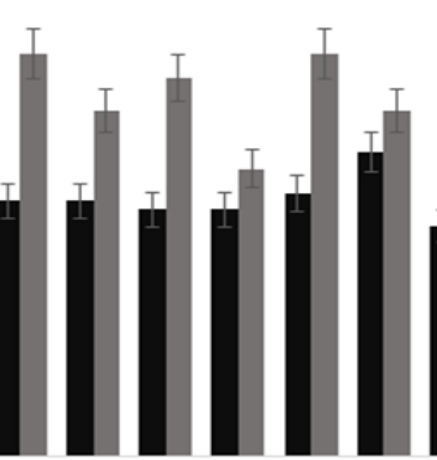

2.00

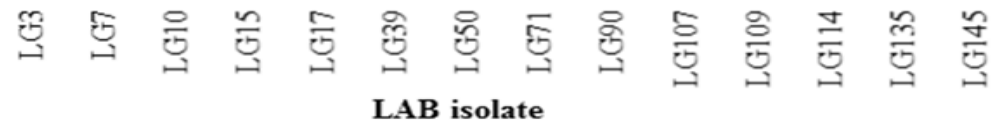
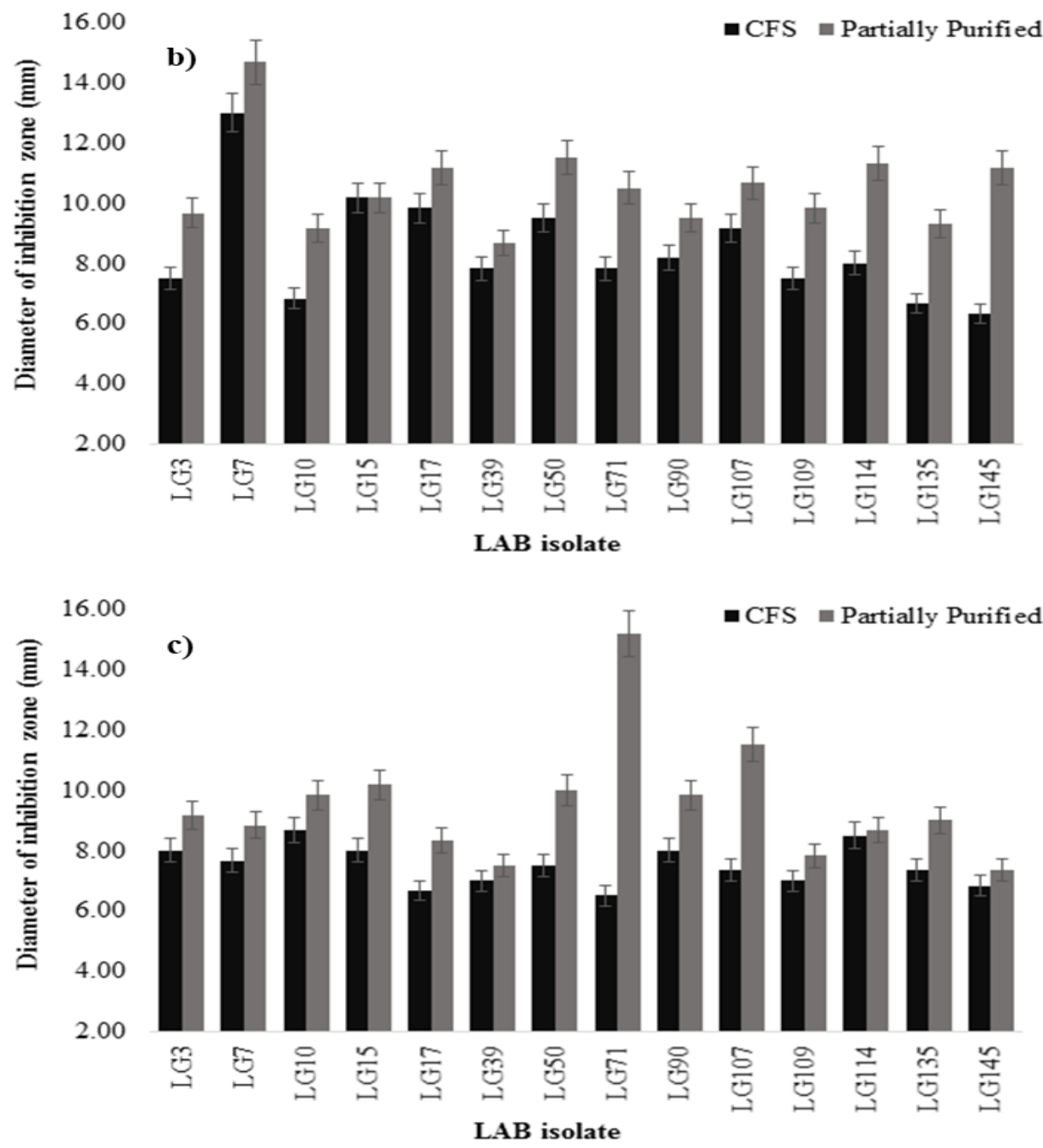

Figure 4. The comparison of inhibition zone of cell-free supernatant (CFS) and partially purified bacteriocin against $S$. typhi (a), S. flexneri (b), L. monocytogenes (c).

In general, Gram-positive bacteria are more sensitive to bacteriocin. The cell wall structure of Gram-positive bacteria has lipopolysaccharide, lipoprotein, and phospholipid composition which is lower than Gramnegative bacteria. The simpler cell wall structure of Gram-positive bacteria is facilitating the easier activity of bacteriocin (Cao-Hoang et al. 2010; Usmiati \& Marwati 2007). Although, some Gram-positive bacteria have been reported resistant to LAB bacteriocins (e.g. nisin, lactocin, enterocin), such as L. monocytogenes, L. innocua, Staphylococcus aureus, Clostridium botulinum, and Bacillus cereus (Garsa et al. 2014; Vignolo et al. 2000). 
This present study showed a wide range of antimicrobial activity against food-spoilage and/or food-borne pathogens, both Gram-positive and Gram-negative bacteria. It indicating that bacteriocin produced by LAB from mangrove sediments are suitable as bio-preservatives for food including fisheries products. Previous independent studies have reported the application of bacteriocinogenic-LAB form nature origin as bio-preservative, such as Lactobacillus curvatus BCS35 marine origin in fish bio-preservation (Gómez-Sala et al. 2016), Leuconostoc sp. application in ground meat to reduce E. coli contamination (Koo et al. 2015). Our present paper did not study the species-specific effects which possibly influence the bacteriocin's efficacy. Therefore, in-vivo studies are urged to perform. As well as, the study to confirm the type and classes of produced bacteriocins, since LAB produces a variety of bacteriocins (Elayaraja et al. 2014).

\section{CONCLUSION}

Our study found 14 bacteriocinogenic-LAB isolates originating from mangrove sediments, Logending Beach Kebumen had a wide range of antimicrobial activity against pathogenic bacteria S. typhi, S. flexneri, and L. monocytogenes. The ANOVA test showed a statistical difference of inhibitory activity between cell-free supernatant and partially-purified bacteriocin and their relationship to the type of indicator pathogenic-bacteria.

\section{AUTHORS CONTRIBUTION}

Conceptualization: DFK; Methodology: TDS, AM, and AR; Investigation: TDS and AM; Writing — original draft preparation: DFK, TDS, and AR; Writing-review and editing: AR.

\section{ACKNOWLEDGMENTS}

The author thanks the Institute of Research and Community Services, Universitas Jenderal Soedirman for funding support through the scheme of DIPA UNSOED 2020.

\section{CONFLICT OF INTEREST}

The author declares that there is no conflict of interest in this study.

\section{REFERENCES}

Aspri, M. et al., 2017. Application of bacteriocin-producing Enterococcus faecium isolated from Donkey milk, in the bio-control of Listeria monocytogenes in fresh whey cheese. International Dairy Journal, 73, pp.19.

Aunpad, R. et al., 2007. Bacteriocins with anti-MRSA activity produced by water and soil isolated bacteria. Annals of Microbiology, 57(1), pp.9-14.

Cao-Hoang, L. et al., 2010. Potential of nisin-incorporated sodium caseinate films to control Listeria in artificially contaminated cheese. Food Microbiology, 27, pp.940-944.

Caridi, A., 2002. Selection of Escherichia coli inhibiting strains of Lactobacillus paracasei subsp. paracasei. Journal of Industrial Microbiology and Biotechnology, 29, pp.303-308.

Castellano, P. et al., 2004. The control of Listeria innocua and Lactobacillus sakei in broth and meat slurry with the bacteriocinogenic strain Lactobacillus casei CRL705. Food Microbiology, 21, pp.291-298.

Chen, H. \& Hoover, D.G., 2003. Bacteriocins and their food application. Comprehensive Reviews in Food Science and Food Safety, 2, pp.82-100. 
Cheong, E.Y.L. et al., 2014. Isolation of lactic acid bacteria with antifungal activity against the common cheese spoilage mold Penicillium commune and their potential as bio-preservatives in cheese. Food Control, 46, pp.91-97.

Cotter, P.D. et al., 2005. Bacteriocins: developing innate immunity for food. Nature Review of Microbiology, 3, pp.777-778.

De-Vuyst, L. \& Leroy, F., 2007. Bacteriocins from lactic acid bacteria: production, purification and food applications. Journal of Molecular Microbiology and Biotechnology, 13, pp.194-199.

Dobson, A. et al., 2012. Bacteriocin production: a probiotic trait?. Applied Environmental Microbiology, 78(1), pp.1-6.

Dupard, T. et al., 2006. Antimicrobial effect of cetylpyridinium chloride on Listeria monocytogenes $\mathrm{V} 7$ growth on the surface of raw and cooked retail shrimp. Journal of Food Science, 71(7), pp.241-244.

Duranti, S. et al., 2017. Maternal inheritance of bifidobacterial communities and bifido-phages in infants through vertical transmission. Microbiome, 5(1), pp.66.

Elayaraja, S. et al., 2014. Production, purification and characterization of bacteriocin from Lactobacillus murinus AU06 and its broad antibacterial spectrum. Asian Pacific Journal of Tropical Biomedicine, 4, pp.305-311.

Elbashir, S. et al., 2018. Seafood pathogens and information on antimicrobial resistance: a review. Food Microbiology, 70, pp.85-93.

Garrido, A. et al., 2012. Development of a multiplex real-time PCR method for simultaneous detection of Salmonella enterica, Shigella flexneri, and Listeria monocytogenes in processed food samples. European Food Research and Technology, 234, pp.571-580.

Garsa, A.K. et al., 2014. Bacteriocin production and different strategies for their recovery and purification. Probiotics and Antimicrobial Protein, 6, pp.47-58.

Gerez, C.L. et al., 2013. Control of spoilage fungi by lactic acid bacteria. Biological Control, 64, pp.231-237.

Gómez-Sala, B. et al., 2016. Strategies to increase the hygienic and economic value of fresh fish: bio-preservation using lactic acid bacteria of marine origin. International Journal of Food Microbiology, 223, pp.41-49.

Hamad, G.M. et al., 2020. Commercial probiotic cell-free supernatants for inhibition of Clostridium perfringens poultry meat infection in Egypt. Anaerobe, 62, pp.102-181.

Hendrati, P.M. et al., 2017. Characterization of bifidobacteria from infant feces with different modes of birth at Purwokerto, Indonesia. Biodiversitas, 18(3), pp.1265-1269.

Iwamoto, M. et al., 2010. Epidemiology of seafood-associated infections in the United States. Clinical Microbiology Review, 23, pp.399-411.

Jennison, A.V. \& Verma, N.K., 2004. Shigella flexneri infection: pathogenesis and vaccine development. FEMS Microbiology Review, 28, pp.43-58.

Koo, O.K. et al., 2015. Antimicrobial potential of Leuconostoc sp. against E. coli O157:H7 in ground meat. Journal of the Korean Society for Applied Biological Chemistry, 58(6), pp.831-838.

Kusharyati, D.F. et al., 2020. Bifidobacterium from infant stool: the diversity and potential screening. Biodiversitas, 21(6), pp.2506-2513.

Liao, S.F. \& Nyachoti, C.M., 2017. Using probiotics to improve swine gut health and nutrient utilization. Animal Nutrition, 3, pp.331-343.

Mahulette, F. et al., 2016. Isolation and characterization of lactic acid bacteria from Inasua. Journal of Tropical Biodiversity and Biotechnology, 1, pp.71.

Martinez, F.A.C. et al., 2013. Bacteriocin production by Bifidobacterium spp.: a review. Biotechnology Advances, 31, pp.482-488. 
Miya, S. et al., 2010. Risk of Listeria monocytogenes contamination of raw readyto-eat seafood products available at retail outlets in Japan. Applied and Environmental Microbiology, 76(10), pp.3383-3386.

Mokhtar, M. et al., 2016. Effect of bacteriocins (from Bifidobacterium spp.) on the prevalence of some Aeromonas and Pseudomonas species in minced meat during cold storage. Journal of Food and Nutritional Disorders, 5(1).

Moradi, M. et al., 2020. Postbiotics produced by lactic acid bacteria: the next frontier in food safety. Comprehensive Reviews on Food Science and Food Safety, 19, pp.3390-3415.

Nithya, K. et al., 2012. Characterization of bacteriocin producing lactic acid bacteria and its application as a food preservative. African Journal of Microbiology Research, 6(6), pp.1138-1146.

Novotny, L. et al., 2010. Morphology and distribution of granulomatous inflammation in freshwater ornamental fish infected with mycobacteria. Journal of Fish Disease, 33, pp.947-955.

Odeyemi, O.A. et al., 2020. Understanding spoilage microbial community and spoilage mechanisms in foods of animal origin. Comprehensive Review in Food Science and Food Safety, 19, pp.311-331.

Pan, X. et al., 2009. The acid, bile tolerance, and antimicrobial property of Lactobacillus acidophilus NIT. Journal of Food Control, 20(6), pp.598-602.

Perez, R.H. et al., 2014. Novel bacteriocins from lactic acid bacteria (LAB): various structures and applications. Microbial Cell Factories, 13(1), pp.113.

Pringsulaka, O. et al., 2012. Partial characterization of bacteriocins produced by lactic acid bacteria isolated from Thai fermented meat and fish products. Food Control, 23(2), pp.547-551.

Scallan, E. et al., 2011. Foodborne illness acquired in the United States major pathogens. Emerging Infectious Disease, 17(1), pp.7-15.

Shahin, K. et al., 2018. Isolation, characterization and genomic analysis of a novel lytic bacteriophage vB_SsoS-IISF002 infecting Shigella sonnei and Shigella flexneri. Journal of Medical Microbiology, 67, pp.376-386.

Siedler, S. et al., 2019. Bio-protective mechanisms of lactic acid bacteria against fungal spoilage of food. Current Opinion in Biotechnology, 56, pp.138-146.

Usmiati, S. \& Marwati, T., 2007. Seleksi dan optimasi proses produksi bakteriosin dari Lactobacillus sp. Jurnal Pascapanen, 4(1), pp.27-37.

Vignolo, G. et al., 2000. Combined effect of bacteriocins on the survival of various Listeria species in broth and meat system. Current Microbiology, 41, pp.410-416.

World Health Organization, 2005. Guidelines for the control of shigellosis, including epidemics due to Shigella dysenteriae type 1. WHO Press: Geneva.

Xi, Q. et al., 2018. Purification and characterization of a bacteriocin produced by a strain of Enterococcus faecalis TG2. Applied Biochemistry and Biotechnology, 184, pp.1106-1119.

Yang, E. et al., 2012. Antimicrobial activity of bacteriocin-producing lactic acid bacteria isolated from cheeses and yogurts. $A M B$ Express, 2, pp.48. 